resistance being strikingly lower in an oncology hospital than in a geriatric unit. ${ }^{11}$

Among strains of $E$ coli, Busk and Korner reported a resistance of $2.5 \%$ in Denmark in 1976-7 before trimethoprim was in clinical use, ${ }^{12}$ and Hamilton-Miller et al reported $7 \cdot 1 \%$ resistance in Britain in 1978-9. ${ }^{8}$ Our present figure in the university hospitals is $4 \cdot 1-6 \cdot 2 \%$.

To facilitate comparison of the results obtained in different countries, MIC breakpoint values should be uniform. A value of $8 \mathrm{mg} / \mathrm{l}$ is best for trimethoprim, based on concentrations achieved in the urine and kidney after therapeutic doses. Using a breakpoint of $2 \mathrm{mg} / \mathrm{l}$ (as used by some workers ${ }^{8}$ ), we found a total resistance (Pseudomonas excluded) of $42.9 \%$ in Turku City Hospital, $15.3 \%$ in Turku University Central Hospital, and $12.2 \%$ in the Kuopio University Central Hospital. An MIC of $1000 \mathrm{mg} / \mathrm{l}$ is used only to define highly resistant strains, which usually show plasmid-mediated resistance.

Resistance to trimethoprim was transferable in about half of our highly resistant $E$ coli strains (unpublished observations). Most of the strains with transferable resistance were collected from Turku City Hospital. Hamilton-Miller et al reported transferability in $25 \%$ of strains highly resistant to trimethoprim ${ }^{8}$; however, the type of wards was not explained.

Our findings call for attention in defining the type of hospital used for a particular study and show that bacterial resistance in different hospitals cannot be compared direct and that one hospital is not representative of a whole country. Secondly, our study shows that the total prevalence of strains resistant to trimethoprim $\geqslant 8 \mathrm{mg} / \mathrm{l}$ in two large university hospitals in

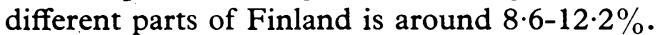

We thank Ms Leena Pulkkinen for excellent technical work and
Drs Kathrine Dornbusch, Antero Kasanen, and Leif Sourander for valuable advice.

\section{References}

${ }^{1}$ Kasanen A, Anttila M, Elfving R, et al. Trimethoprim. Pharmacology, antimicrobial activity and clinical use in urinary tract infections. $A n n$ Clin Res $1978 ; 10$,suppl $22: 1-39$.

" Huovinen P, Toivanen P. Trimethoprim resistance in Finland after five years' use of plain trimethoprim. Br Med $\mathcal{f} 1980 ; 280: 72-4$.

${ }^{3}$ Lennette EH, Spaulding EH, Truant JP. Manual of clinical microbiology. 2nd ed. Washington DC: American Society for Microbiology, 1976.

4 Lindberg AA, Nord C-E, Hellgren M, et al. Identification of Gramnegative aerobic fermentors in a clinical bacteriology laboratory. Med Microbiol Immunol (Berl) $1974 ; 159: 201$.

${ }^{5}$ Ericsson HM, Sherris JC. The agar plate dilution method. Acta Pathol Microbiol Scand (B) 1971 ;suppl 217:11.

${ }^{6}$ Alestig K, Dornbusch K, Ericsson $\mathrm{C}$, et al. Resistensbestämning av bakterier : Ny indelning i känslighetsgrupper-S, I och R. Läkartidningen $1978 ; 75: 4346-8$.

7 Swedish Reference Group for Antibiotics. A revised system for antibiotic sensitivity testing. Scand 7 Infect Dis 1981;13:148-52.

${ }^{8}$ Hamilton-Miller JMT, Gooding A, Brumfitt W. Resistance to trimethoprim in 1978-79 compared with 1973-75. F Clin Pathol 1981;34:439-42.

${ }^{9}$ Amyes SGB, Emmerson AM, Smith JT. R-factor mediated trimethoprim resistance: result of two three-month clinical surveys. 7 Clin Pathol $1978 ; 31: 850-4$

10 Grüneberg RN. Co-trimoxazole: effects on the urinary and bowel flora. In: van der Waaij D, Verhoef J, eds. New criteria for antimicrobial therapy. Amsterdam-Oxford: Excerpta Medica, 1979.

${ }_{11}$ Dornbusch K, Toivanen P. Effect of trimethoprim or trimethoprim/ sulphamethoxazole usage on the emergence of trimethoprim resistance in urinary tract pathogens. Scand F Infect Dis 1981;13:203-10.

1. Busk HE, Korner B. Trimethoprim resistance in Finland. Br Med 71980 ; 280:1054-5.

(Accepted 30 November 1981)

\title{
Variations in cancer mortality among local authority areas in England and Wales: relations with environmental factors and search for causes
}

\author{
M J GARDNER, P D WINTER, E D ACHESON
}

\begin{abstract}
Geographical variations in specific causes of mortality among the 1366 local authority areas of England and Wales as defined at 1971 were studied by examining extracts from death certificates held on computer tape. Five items of information on each death-year of death, age at death, sex, local authority area of residence, and the underlying cause of death, during the 11 years 1968-78 -permitted a more detailed investigation than had been possible before.
\end{abstract}

Analysis of some early results of the study-including maps of mortality for pleural mesothelioma, nasal cancer, and bladder cancer-suggested that, despite the known limitations of death certification, systematic study of the

\footnotetext{
Medical Research Council's Environmental Epidemiology Unit, University of Southampton, Southampton General Hospital, Southampton SO9 4XY

M J GARDNER, BSC, PHD, reader in medical statistics

$P$ D WINTER, BSC, MSC, computer programmer and statistician

E D ACHESON, FRCP, FFCM, professor of clinical epidemiology and director of unit
}

mortality of small areas may give clues to aetiological factors in the environment. Analyses relating mortality to the distribution of environmental factors and examining disease profiles of each area may also provide clues. These will be followed up by other methods of study, such as case-control techniques.

\section{Introduction}

There have been substantial variations in mortality from one part of Britain to another for at least 80 years. ${ }^{12}$ With exceptions for certain causes, death rates are higher in the north and west than in the south and east. In the latest report on area mortality from the Office of Population Censuses and Surveys, covering the years 1969-73, overall mortality was shown to be about $20 \%$ higher in the North-western region than in the East Anglian. Past studies of geographical variations in mortality have generally used large areas (such as regions or counties) or county and London boroughs and included deaths from only a limited number of years. ${ }^{34}$ This has led to restricted investigation of the less common causes of death, particularly in small areas, so that there may be unsuspected geographical clues to causes of disease buried in the data. We have explored how known industrial carcinogens might have been detected in this way. 


\section{Methods}

We obtained extracts of all primary death records for the period 1959-79 on computer tape from the Office of Population Censuses and Surveys. During these 21 years nearly 12 million deaths were registered in England and Wales, and we had five items of information on each - namely, year of death, sex, age at death, the local authority area code of place of residence at the time of death, and the code number of the underlying cause of death according to the International Classification of Diseases (ICD). We have no means of identifying any of the deceased persons personally.

There are problems associated with simply amalgamating all the mortality data for the years $1959-79$ by cause and area for three reasons. Firstly, the ICD has passed successively through its seventh, eighth, and ninth Revisions, which do not always allow continuity of classification by cause of death. Secondly, there was a major reorganisation of local authority area boundaries in 1974, and other changes occurred continually on a small scale. For each death registered from 1974 onwards, however, we also had the area of residence coded to the pre-1974 boundaries. Thirdly, population figures for each local authority area by age and sex were available only for the census years 1961 and 1971, but during the 21 years there would have been changes in population structure due to births, deaths, and migration. Since these might have distorted analyses dependent on population-based rates, such as standardised mortality ratios, we also calculated proportional mortality ratios based both on all deaths and on all deaths from cancer. As the findings were similar with each approach, the results in this paper are described using standardised mortality ratios only.

We intend to produce an atlas of mortality by cause from these data for the 1366 local authority areas, and we give some examples here. So far we have analysed deaths which occurred during the period of the eighth revision of the ICD (1968-78) using the boundaries and population figures as at the 1971 Census, and have concentrated on malignant neoplasms.

We are also collecting historical and current environmental data so that we can search for interrelations with the mortality rates. In particular, data about the employed population by place of residence according to the industry in which they work are being related to death rates from cancer.

Age standardisation of rates was carried out by the indirect method, producing standardised mortality ratios (SMRs). SMRs are for all ages and were evaluated for statistical significance using the standard test based on the Poisson distribution. ${ }^{5}$

\section{Results}

Fig 1 shows the geographical pattern of mortality from pleural mesothelioma in men during 1968-78. Deaths included were those coded to underlying cause as 163.0 (malignant neoplasm of the pleura) in the eighth revision of the ICD. During 1976-8-the period for which the Office of Population Censuses and Surveys was able to calculate a proportion- $89 \%$ of male deaths with this code number were certified as due to mesothelioma of the pleura (personal communication). Areas shown in fig 1 are those with SMRs in the top tenth of the distribution-that is, among the 137 areas with highest SMRs-and also significantly raised above the average of 100 at the $1 \%$ level. The value of the top decile in this case is an SMR of 226 , and all areas indicated had an SMR of that size or greater.

Fig 1 shows a predominance of areas around the main naval dockyards and ports, with another cluster on the east side of London. This geographical distribution was as expected from knowledge about the extremely high use of asbestos, particularly crocidolite, in shipbuilding and repairing in the relevant past. ${ }^{6}$ Also the places shown in London are centred on Barking, which was the site of a factory where crocidolite, amosite, and chrysotile asbestos were used in the manufacture of a wide range of products from 1913 to $1967 .{ }^{8}$ Other factories as well as dockyards were also located in this vicinity. The individual area with the largest number of excess deaths was Plymouth, with 74 observed deaths compared with seven expected on the basis of its population size and structure.

Fig 2 shows local authority areas with raised SMRs (the top decile is 233) for cancer of the nose, nasal cavities, middle ear, and accessory sinuses (ICD 160) in men. Of the five areas shown there was a ready explanation for three. High Wycombe and Wycombe are associated with the furniture industry, and Rushden in Northamptonshire with the manufacture of boots and shoes. ${ }^{910}$ Of the two other areas, Tower Hamlets has had a large furniture industry for a considerable time.

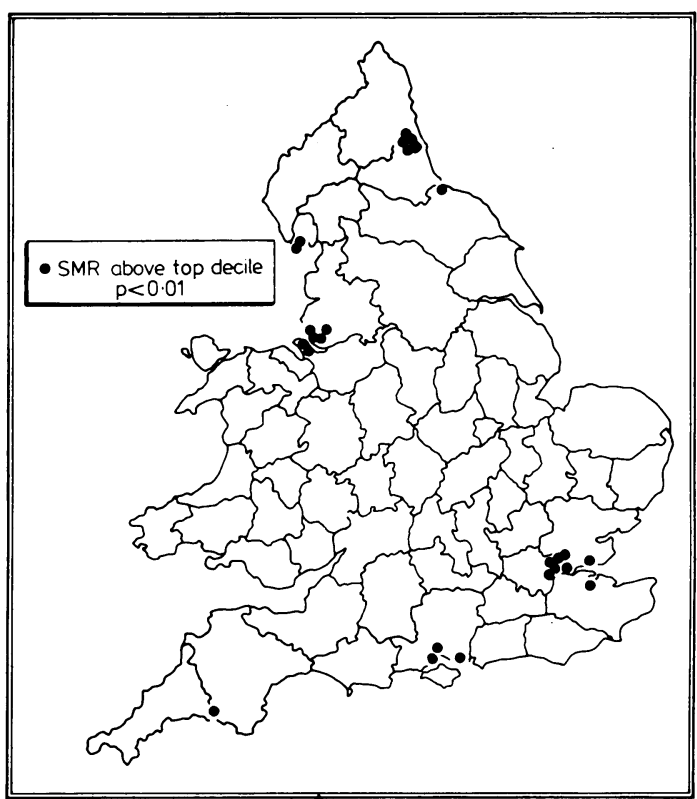

FIG 1-Local authority areas with raised mortality from mesothelioma of pleura in men during 1968-78. Areas shown are: Barking London Borough, Barrow-in-Furness County Borough, Bexley LB, Birkenhead CB, Bootle CB, Brentwood Urban District, Canvey Island UD, Crosby Municipal Borough, Daltonin-Furness UD, Gillingham MB, Havering LB, Hebburn UD, Hindley UD, Jarrow MB, Kirkby UD, Longbenton UD, Newcastle upon Tyne CB, New Forest Rural District, Newham LB, Plymouth CB, Portsmouth CB, Southampton CB, Teesside $\mathrm{CB}$, Thurrock UD, Wallasey $\mathrm{CB}$, and Wallsend $\mathrm{MB}$.

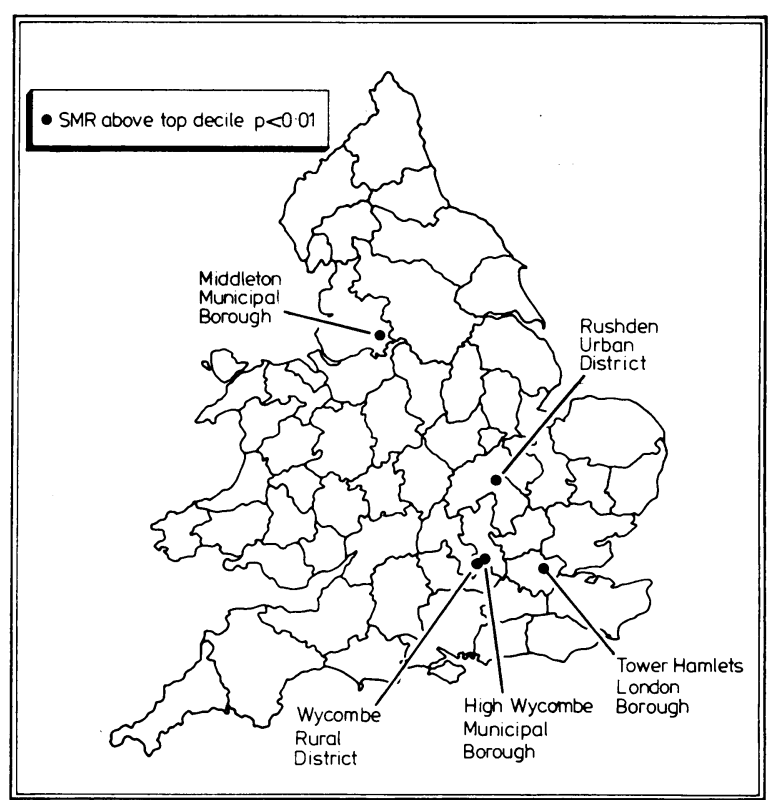

FIG 2-Local authority areas with raised mortality from cancer of nose, nasal cavities, middle ear, and accessory sinuses in men during 1968-78.

Pleural mesothelioma and nasal cancer were chosen deliberately from tumours with relatively low incidence for which maps of mortality rates had not been produced previously. Also they are cancers for which aetiological influences are known and there are large associated relative risks.

Bladder cancer has a higher incidence, but earlier maps were limited to larger areas. Fig 3 shows the detailed distribution of bladder cancer (ICD 188) in men during 1968-78, indicating those among the 1366 local authority areas with raised death rates. Fig 3 not only shows areas according to the same criteria as figs 1 and 2 but includes areas with SMRs in the top tenth of the distribution (in this case, over 135) 
that were statistically significant at the 5\% level and areas with SMRs that were not in the top tenth but were significant at the $1 \%$ level. The main locations of areas with raised SMRs were in parts of north central England where there had been concentrations of the dyestuffs and rubber industries, and in and near London.

The general pattern of fig 3 is well known but the specific identification of local authority areas such as urban districts, municipal boroughs, and rural districts with high mortality is now possible. The apparent excess mortality in several areas cannot be explained on the basis of known industrial carcinogens, and we shall investigate them further.

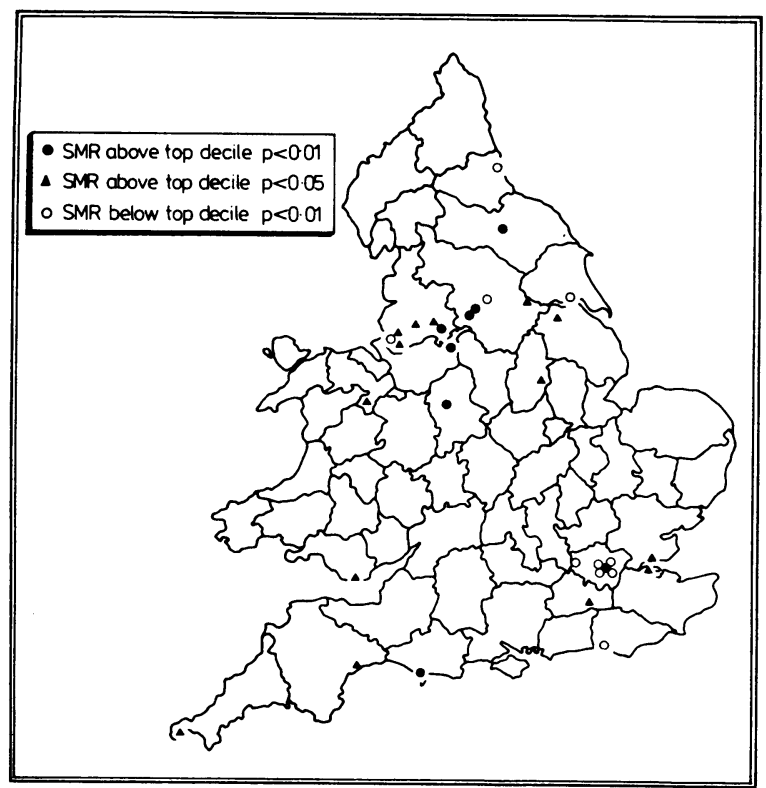

FIG 3-Local authority areas with raised mortality from cancer of bladder in men during 1968-78. Areas shown are: Bredbury and Romiley Urban District, Droylsden UD, Huddersfield County Borough, Mirfield UD, Northallerton UD, Southwark London Borough, Stone Rural District, Weymouth and Melcombe Regis Municipal Borough. A Barry MB, Budleigh Salterton UD, Canvey Island UD, Ceiriog RD, Dorking and Horley RD, Gravesend MB, Kirkby UD, Little Lever UD, Middleton MB, Newark MB, Penzance MB, Scunthorpe MB, Selby UD, Widnes MB. O Brighton CB, Hillingdon LB, Kensington and Chelsea LB, Kingston upon Hull CB, Lambeth LB, Leeds CB, Lewisham LB, Liverpool CB, Sunderland CB, Tower Hamlets LB.

One of the initial uses of our bank of environmental data was to look at the relation of nasal cancer to industry. We searched for industries common to the five places shown in fig 2 in which men were employed on a large scale compared with the remaining 1361 areas of England and Wales. Using data from the 1971 Census on employment in 207 different industrial classifications, ${ }^{11}$ we looked for industries in which both the number and proportion of local men employed were in the top tenth of the respective distributions among the local authority areas. Table I shows the industries found to be large employers in three or more of the five areas.

There was no industry for which all five places were in the top tenth. Tailoring of women's garments, however, was common to all except Wycombe Rural District, and a risk of nasal cancer in the tailoring and dressmaking industry has been suggested previously.12 Two industries were relatively large employers of men in three areas -namely, the furniture and upholstery industry and the production of leather goods. The first of these is mentioned above and the second is associated with the boot and shoe industry.

We are also studying the mortality data by focusing on the disease profile of individual local authority areas, rather than examining the geographical profile of each cause of death. Table II shows an example for women in Weymouth and Melcombe Regis Municipal Borough.

A high SMR from all malignant neoplasms combined was found among women in the town during 1968-78. This was associated principally with higher death rates from cancer of the colon (ICD 153) cancer of the ovary (ICD 183), and cancer of the peritoneum (ICD
158.9), which together accounted for 47 of the 73 excess deaths from cancer: no other individual site of cancer had a significantly raised SMR. On the other hand, among women in Weymouth overall there were 46 fewer deaths than expected. This was due to 119 fewer deaths from causes other than cancer than expected on the basis of the age structure of the town's female population.

\section{Discussion}

Our studies indicate that a detailed geographical analysis of mortality can detect associations between cancers and known carcinogens. Despite known limitations in the accuracy of death certifications, the results depict patterns that point to industrial carcinogens which are known to play a part in the aetiology of these tumours. Thus in respect of pleural mesothelioma wellknown areas of high usage of asbestos in the relevant past are clearly identified and a cause effectively mapped. Furthermore, if analysis is limited to deaths under the age of 75 similar findings emerge.

Mortality statistics by area have also been criticised because comparisons might be biased through the effects of betweenarea migration. Remarkably, however, our maps closely reflected the exposure to the aetiological agent some two decades or more previously. Migration from one area to another between the time of action of the carcinogens and death from the tumour had not been enough to obliterate the patterns.

Nevertheless, the test of the method is whether it will lead to the detection of unknown carcinogens. The original suggestion that adenocarcinoma of the nose and nasal sinuses might be related to work in the furniture industry came from an astute clinical observation by Hadfield and Macbeth, ENT surgeons in High Wycombe and Oxford, respectively. ${ }^{13}$ During the subsequent epidemiological study in the region covered by the Oxford Cancer Register another focus of high incidence was noted in Northamptonshire, which happened to lie within this area and where there was no major furniture industry. Further detailed evidence disclosed an association with working in the

TABLE I-Industries in five areas with raised mortality from nasal cancer (see fig 2) where number and percentage of local men employed in industry are in top tenth of distributions among 1366 local authority areas

\begin{tabular}{|c|c|c|c|}
\hline $\begin{array}{l}\text { No of } \\
\text { common } \\
\text { areas }\end{array}$ & $\begin{array}{c}\text { No of } \\
\text { classified } \\
\text { industries }\end{array}$ & Common areas & Industry* \\
\hline $\begin{array}{l}5 \\
4\end{array}$ & $\begin{array}{l}0 \\
1\end{array}$ & \multirow{4}{*}{$\begin{array}{l}\text { High Wycombe Urban District, } \\
\text { Middleton Municipal Borough, } \\
\text { Rushden UD, Tower Hamlets } \\
\text { London Borough } \\
\text { High Wycombe UD, Wycombe } \\
\text { Rural District, Tower Hamlets LB } \\
\text { Middleton MB, Rushden UD, Tower } \\
\text { Hamlets LB } \\
\text { 10 are High Wycombe UD, } \\
\text { Wycombe RD }\end{array}$} & \multirow{4}{*}{$\begin{array}{l}\text { Women and girls' } \\
\text { tailored outwear } \\
\text { (443) } \\
\text { Furniture and } \\
\text { upholstery (472) } \\
\text { Leather goods } \\
\text { (432) }\end{array}$} \\
\hline 3 & 2 & & \\
\hline 2 & 21 & & \\
\hline $\begin{array}{l}1 \\
0\end{array}$ & $\begin{array}{r}65 \\
118\end{array}$ & & \\
\hline Total & 207 & & \\
\hline
\end{tabular}

*Industries according to Standard Industrial Classification. ${ }^{1}$

TABLE II-Mortality among women at all ages in Weymouth and Melcombe Regis Municipal Borough during 1968-78

\begin{tabular}{lccc}
\hline \multirow{2}{*}{ Cause of death } & \multicolumn{2}{c}{ Deaths } & $\begin{array}{c}\text { Standardised } \\
\text { mortality } \\
\text { ratio }\end{array}$ \\
\cline { 2 - 3 } & Observed & Expected & 99 \\
\hline All causes & 3350 & 3396 & $111^{* *}$ \\
All malignant neoplasms & 706 & 633 & 96 \\
All other causes & 2644 & 2763 & $137^{* *}$ \\
Malignant neoplasm of: & 98 & 71 & $141^{*}$ \\
$\quad$ Colon (153) & 57 & 40 & $384^{*}$ \\
Ovary (183) & 4 & 1 & \\
Peritoneum (158.9) & & &
\end{tabular}

Figures in parentheses are ICD code numbers.
${ }^{p}<0.05 *{ }^{*} p<0.01$. 
leather boot and shoe manufacturing industry. ${ }^{10}$ So these two causes of this tumour were discovered through keen perception and serendipity. From the results shown in fig 2 and table I, however, the systematic investigation that we are undertaking would probably have led to their discovery-at least now, if not in the 1960s. An earlier preliminary analysis of mortality from cancer of the bladder in men and the distribution of industry showed an association with precision-engineering manufacture, ${ }^{14}$ which includes the production of gears, a process requiring the use of cutting oils (B Pannett, personal communication). Engineers working with metal, such as toolsetters, have recently been shown in a case-control study to have a high relative risk of bladder cancer ( $\mathrm{R}$ A Cartwright, personal communication), though other studies, such as one in Finland of men exposed to oil mist in the metal-machining industry, have reported no such association. ${ }^{15}$

An atlas of cancer mortality for the United States identified previously unrecognised areas of high mortality for cancers of various sites. ${ }^{16}$ Some of these relate to the action of known carcinogens, such as asbestos or the use of tobacco snuff inside the mouth. ${ }^{1{ }^{18}}$ In other cases the geographical pattern has led to new hypotheses, which are being tested. One difficulty, of course, is that, as a result of the large number of relations that will be examined, many associations will be suggested. Some of these will be false-positive leads due either to chance or to the effect of confounding variables, and caution will be needed in the choice of which leads to pursue.

We intend, as a next step, to produce an atlas of cancer mortality for England and Wales along the lines of that published for the United States. ${ }^{16}$ We have obtained the national grid co-ordinates of the boundaries of the 1366 local authority areas from the Department of the Environment on magnetic tape, and propose to use the computer to draw maps. Initially these will be based on the pre-1974 boundaries, but when 1981 Census population figures become available for the new boundaries it will be possible to study these also. There are interesting questions to be answered about how to display the numerical value, ranking, and statistical significance of the death rate in a local authority area, as well as possibly its size and population.

The pattern of mortality within each local authority area may also be enlightening. If anatomically or physiologically related sites show raised SMRs then a common local cause might be suggested. On the other hand, if a diverse collection of cancers have raised SMRs then plausible leads may not be so apparent. The routine data, combined with acquired local knowledge and insight, might be helpful in either case. In a situation such as shown in table II there are suggestions that women exposed to asbestos have higher rates of ovarian cancer as well as peritoneal mesothelioma, ${ }^{1920}$ and we are investigating occupations of women in Weymouth in the past. The apparent excess of deaths from cancer of the ovary in women exposed to asbestos may be an artefact resulting from misdiagnosis of deaths due to peritoneal mesothelioma: we are investigating this. An extension of the use of disease profiles would be to group together areas with similar profiles and then examine the areas within groups for sharing of possible exposure to causal factors.

The maps and relations should be regarded only as giving clues to possible causative factors. Further studies, in which information on individuals is collected, will be necessary to follow ideas highlighted from the geographical pattern: several of these are planned.

We thank Mrs S Webber and Miss R Kirby for statistical help, and Miss J Kirk for typing the manuscript.

\section{References}

${ }^{1}$ Adelstein AM. Current vital statistics: methods and interpretation. $\mathrm{Br}$ Med f 1978;ii:983-7.

${ }^{2}$ Barker DJP. Geographical variations in disease in Britain. $\mathrm{Br}$ Med $\mathcal{F} 1981$; $283: 398-400$.

${ }^{3}$ Office of Population Censuses and Surveys. Area mortality decennial supplement, 1969-73, England and Wales. London: HMSO, 1981.

4 Gardner MJ, Crawford MD, Morris JN. Patterns of mortality in middle and early old age in the county boroughs of England and Wales. $\mathrm{Br} \mathcal{F}$ Prev Soc Med 1969;23:133-40.

${ }^{5}$ Armitage P. Statistical methods in medical research. Oxford: Blackwell Scientific Publications, 1971.

6 Wagner JC, Berry G, Timbrell V. Epidemiology of asbestos cancers. $\mathrm{Br}$ Med Bull 1971;27:71-6.

${ }^{7}$ Greenberg M, Lloyd Davies TA. Mesothelioma register 1967-68. Br $\mathcal{F}$ Ind Med $1974 ; 31: 91-104$.

${ }^{8}$ Newhouse ML, Berry G. Patterns of mortality in asbestos factory workers. Ann NY Acad Sci 1979;330:53-66.

${ }^{9}$ Acheson ED, Cowdell RH, Hadfield EH, Macbeth RG. Nasal cancer in woodworkers in the furniture industry. Br Med $\mathcal{F} 1968$;ii:587-96.

${ }^{10}$ Acheson ED, Cowdell RH, Jolles B. Nasal cancer in the Northamptonshire boot and shoe industry. Br Med f 1970;ii :385-93.

11 Office of Population Censuses and Surveys. Standard industrial classification. London: HMSO, 1968.

12 Acheson ED, Cowdell RH, Rang EH. Nasal cancer in England and Wales: an occupational survey. $B r \mathcal{F}$ Ind Med $1981 ; 38: 218-24$.

13 Macbeth RG. Malignant disease of the paranasal sinuses. 7 Laryngol Otol $1965 ; 79: 592-612$.

${ }^{14}$ Acheson ED, Gardner MJ, Winter PD. Towards a strategy for the identification of occupational carcinogens in England and Wales-a preliminary report. In: Peto R, Schneiderman M, eds. Banbury Report 9: quantification of occupational cancer. New York: Cold Spring Harbor Laboratory, 1981 .

15 Jarvolm B, Lillienberg L, Sallsten G, Thiringer G, Axelson O. Cancer morbidity among men exposed to oil mist in the metal industry. $\mathcal{F O M}$ $1981 ; 23: 333-7$.

${ }^{16}$ Mason TJ, McKay FW, Hoover R, Blot WJ, Fraumeni JF. Atlas of cancer mortality for US counties: 1950-1969. Washington: US Government Printing Office, 1975.

17 Blot WJ, Fraumeni JF, Mason TJ, Hoover RN. Developing clues to environmental cancer: a stepwise approach with the use of cancer mortality data. Environ Health Perspect 1979;32:53-8.

18 Blot WJ, Fraumeni JF. Geographical patterns of oral cancer in the United States: etiological implications. F Chronic Dis 1977;30:745-57.

19 Newhouse ML, Berry G, Wagner JC, Turok ME. A study of the mortality of female asbestos workers. Br F Ind Med 1972;29:134-41.

${ }^{20}$ Wignall B, Fox AJ. Mortality of female gas mask assemblers. $\mathrm{Br} \mathcal{F}$ Ind Med (in press).

(Accepted 7 December 1981)
MEDICINES APPROPRIATED TO THE STOMACH-By stomach, I mean that ventricle which contains the food till it be concocted into chyle. Medicines appropriated to the stomach are usually called stomachicals. The infirmities usually incident to the stomach are three. 1. Appetite lost. 2. Digestion weakened. 3. The retentive faculty corrupted. When the appetite is lost, the man feels no hunger when his body needs nourishment. When digestion is weakened it is not able to concoct the meat received into the stomach, but it putrifies there. When the retentive faculty is spoiled the stomach is not able to retain the food till it be digested, but either vomits it up again, or causes fluxes. Such medicines then as remedy all these, are called stomachicals. And of them in order. 1. Such as provoke appetite are usually of a sharp or sourish taste, and yet withal of a grateful taste to the palate, for although loss of appetite may proceed from divers causes, as from choler in the stomach, or putrefied humours or the like, yet such things as purge this choler or humours, are properly called Orecticks, not stomachicals; the former strengthen appetite after these are expelled. 2. Such medicines help digestion as strengthen the stomach, either by convenient heat, or aromatic (viz spicy) faculty, by hidden property, or congruity of nature. 3. The retentive faculty of the stomach is corrected by binding medicines, yet not by all binding medicines neither, for some of them are adverse to the stomach, but by such binding medicines as are appropriated to the stomach. For the use of these. Use not such medicines as provoke appetite before you have cleansed the stomach of what hinders it. Such medicines as help digestion, give them a good time before meat that so they may pass to the bottom of the stomach, (for the digestive faculty lies there), before the food come into it. Such as strengthen the retentive faculty, give them a little before meat, if to stay fluxes, a little after meat, if to stay vomiting. (Nicholas Culpeper (1616-54) The Complete Herbal, 1850.) 